\title{
The bidirectional relationship between entrepreneurial intention and entrepreneurial competencies for nascent and existing entrepreneurs
}

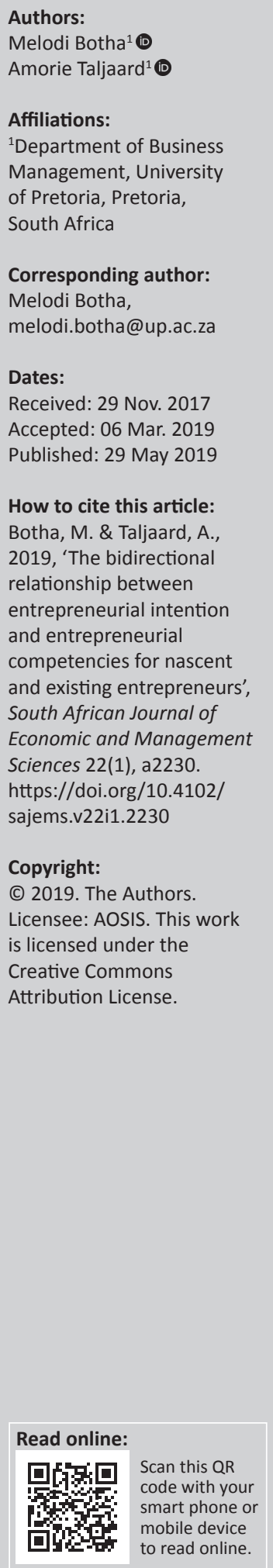

Background: Although many scholars focus their research efforts on predicting entrepreneurial intention, these scholars have not determined the bidirectional relationship between entrepreneurial intention and competencies.

Aim: This article investigates whether entrepreneurial intention and various individual entrepreneurial competencies influence each other. The human agency and social cognitive theories suggest that these constructs have bidirectional relationships. Furthermore, the direction and strength of these relationships are established.

Setting: Results from a sample of 342 nascent and existing entrepreneurs from South Africa are drawn.

Method: A quantitative research study is undertaken and structural equation modelling conducted. As far as could be determined, this study is the first to test the model fit between entrepreneurial intention and the individual entrepreneurial competencies in one model.

Results: The findings provide evidence of a bidirectional relationship between entrepreneurial intention and various entrepreneurial competencies, and the outcome thereof might lead to an increased business start-up. The strongest positive relationships were observed between entrepreneurial intention and self-efficacy, opportunity recognition, conveying a compelling vision, value creation through innovation (observing customer usage) and perseverance. Previous scholars confirmed that self-efficacy is a strong predictor of entrepreneurial intention. The article found a moderate positive significant bidirectional relationship between entrepreneurial intention and self-efficacy.

Conclusion: The findings could assist policy-makers, educators, as well as potential, nascent and start-up entrepreneurs with the understanding that these specific entrepreneurial competencies are necessary for a successful business venture or for moving to the next stage of the venture life cycle. In addition to the previously mentioned practical implications, this study also shows educators, policy-makers and academics that they need to adapt their entrepreneurial training programmes to ensure that self-efficacy and entrepreneurial intention are taught simultaneously as these constructs influence each other.

Keywords: Entrepreneurial intention; individual entrepreneurial competencies; bidirectional relationship; self-efficacy; nascent and existing entrepreneurs.

\section{Introduction}

Economic development highlights the importance of understanding entrepreneurship, and recognises that both factor- and efficiency-driven economies express high levels of entrepreneurial intentions (Kelley, Singer \& Herrington 2017). Thompson (2009:676) defines entrepreneurial intention as ' ... the self-recognition by an individual that they intend to set up a new business venture at some point in the future'. When studying actual new venture launches, Krueger (2017) comments on the importance of understanding the preconditions that enable entrepreneurial activity. 'We often seek to develop more entrepreneurial students and trainees in the classroom and communities, but in fact, we need to develop better entrepreneurs' (Krueger 2017:51). The complexity of the tasks required by entrepreneurs dictates that they need to prepare themselves with relevant competencies that could be used in developing a successful venture (Ahmad, Halim \& Zainal 2010:73).

A number of comprehensive studies have been conducted to investigate the predictors of entrepreneurial intention (Hmielski \& Corbett 2006:3, 19; Krueger, Reilly \& Carsrud 2000; 
Lüthje \& Franke 2003; Obschonka, Silbereisen \& SchmittRodermund 2010; Schwarz et al. 2009), specifically with entrepreneurial intention as the outcome variable (Autio et al. 2001; Krueger 1993; Reitan 1996). At the same time, Thompson (2009:670) states that 'entrepreneurial intention is a useful construct in its own right that can be used not only as a dependent variable (DV), but also as an independent variable (IV) where intentions can lead to outcomes'. These outcomes include behaviours such as opportunity recognition, entrepreneurial action, increased entrepreneurial performance and the actual start-up of businesses. Yet, there is limited empirical evidence in which entrepreneurial intention is treated as a predictor of these outcomes, with the exception of studies by Ibrahim and Abdullahi (2014) and Ibrahim and Lucky (2014). However, these studies were limited to student samples in Nigeria, and they recommended that future studies should include a more comprehensive and representative sample.

Researchers such as Morris et al. (2013) focused their research efforts on entrepreneurial competencies (Bird 1995; Brophy \& Kiely 2002; Kaur \& Bains 2013; Morris et al. 2013). Entrepreneurial competencies can be defined as the skills, knowledge, values, attitudes and behaviours or a combination thereof that individuals need to perform a specific activity, such as starting and running a successful business (Brophy \& Kiely 2002:166; Kaur \& Bains 2013; Morris et al. 2013:353). In this article, the entrepreneurial competencies are investigated from a behavioural lens (Kiggundu 2002), where each competency is an activity or action. This article is supported by the social cognitive theory (Bandura 1989) and human agency theory (Bandura 2001) to link entrepreneurial competencies and intentions from a psychological perspective on a behavioural level (Biraglia \& Kadile 2017; Bird 1988; Krueger 1993; Zhao \& Seibert 2006). Just like strategy, entrepreneurship has begun to wrestle with the psychological micro-foundations of its phenomenon, such as the 'entrepreneurial mindset' (Krueger \& Welpe 2014:1). According to Bandura (1989:1179), action is motivated and directed by cognitive goals. Personal goal setting is influenced by perceived capabilities and competencies, identified by a self-efficacy process (Bandura 1989:1175). The social cognitive theory, therefore, posits a multifaceted causal structure that addresses both the development of competencies and the regulation of action (Bandura 1986). The agent (agentic perspective of social cognitive theory) is the individual that intentionally makes something happen that is represented by a present cognitive goal (Bandura 2001:1, 3). Human cognition is known as the 'semantic layer', referring to what we say and do. Below this layer is the 'symbolic level', which holds all beliefs, attitudes and assumptions. However, below the semantic layer is the neurological layer, which represents the biological substrate of cognition (Krueger 2017:62). Previous studies have modelled entrepreneurial competencies (Mitchelmore \& Rowley 2010) and entrepreneurial intention (as suggested by Thompson 2009) as outcomes in separate models. However, the Theory of Planned Behaviour by Ajzen (1991) and the Social Cognitive Theory by Bandura (1989) lead us to question whether high levels of individual entrepreneurial intention are the cause of early entrepreneurial competence in the venture life cycle, which may lead to greater business start-up success and entrepreneurial action. Previous scholars have established that, although the entrepreneurial intention of potential entrepreneurs may be high (Singh, Verma \& Rao 2016), the start-up rate of these individuals moving into entrepreneurial action is significantly low (Nabi, Holden \& Walmsley 2010). As stated by Al Mamun, Nawi and Shamsudin (2016:110), entrepreneurial action starts with entrepreneurial intention, which is formed through personality traits and competencies. Thus, if entrepreneurial intentions predict behaviour and behaviour predicts action (Fayolle, Kyrö \& Liñán 2015), competencies should be further investigated from an input (antecedents to competencies) and process point of view (task of behaviour leading to competencies) (Man, Lau \& Chan 2002:131). According to Weinert (2001), a range of dimensions influence an individual's degree of competency, which includes experience, knowledge, ability, understanding, skill, action and motivation. Although educational programmes can produce entrepreneurial intentions, there is a need to better understand whether entrepreneurship education in its current form increases perceived behavioural control (Fayolle, Gailly \& Lassas-Clerc 2006), and leads to greater business start-up success and action within nascent entrepreneurs. Studies have shown that approximately two-thirds of nascent entrepreneurs disengage from initial venturing efforts before they eventually start a business (Reynolds 2007). Therefore, a shift is required, from studying intentions and business formation to studying successful business development and growth (Morris et al. 2013:363), and a bidirectional relationship between the constructs, in this article, might enforce such a shift.

Therefore, the purpose of this article is twofold. The first part is to investigate whether entrepreneurial intention has a bidirectional relationship with certain individual entrepreneurial competencies. Competencies are seen as behavioural outcomes in this article because competency refers to the quality of action (Bird 1995), and therefore if a bidirectional relationship is evident between entrepreneurial intention and the entrepreneurial competencies, it might enhance the outcomes such as business start-up or entrepreneurial action. The second part is to determine the direction and strength of the relationships between entrepreneurial intention and individual entrepreneurial competencies. Mitchelmore and Rowley (2010:97) state that entrepreneurial competencies should be measured at different stages of the entrepreneurial venture, as different competencies are required at each stage. Hence, we include a sub-sample of nascent entrepreneurs and a sub-sample of existing entrepreneurs. The entrepreneurial intention of existing entrepreneurs is measured to establish whether the respondents are interested in starting another business in the near future. Scholars such as Thompson (2009) and Zhao, Seibert and Lumpkin (2010) have also focused on measuring repeat entrepreneurial intention on existing entrepreneurs.

We contribute to the entrepreneurial intention construct and intention models because Thompson (2009:670) suggested that entrepreneurial intention can be treated as a predictor of 
outcomes such as behaviours, action and business start-up. Yet, limited studies embarked on investigating Thompson's notion. Therefore, this article determines the inverse relationship between entrepreneurial intention and entrepreneurial competencies, and tests bidirectional relationships which could enhance these outcomes. By challenging the existing body of knowledge where entrepreneurial intention was previously only tested as a DV, it might encourage other scholars to explore new avenues of testing entrepreneurial intention in different settings, contexts and countries. Furthermore, educators and policymakers, interested in promoting entrepreneurship, can pay attention to the specific entrepreneurial competencies that have a bidirectional relationship with entrepreneurial intention. The competencies with the strongest relationships can be included in start-up training programmes for potential and nascent entrepreneurs to enhance business start-up success. As previous work confirmed that self-efficacy is a strong predictor of entrepreneurial intention (Bronowitz \& Rader 2008; Kolvereid 1996; Pfeifer, Šarlija \& Zekić Sušac 2016; Wakkee, Elfring \& Monaghan 2010), and self-efficacy is identified as an entrepreneurial competency that has a direct effect on behaviour (Morris et al. 2013:363), it is important to determine whether entrepreneurial intention and selfefficacy influence each other. This is an important occurrence necessary for business success (Boyd \& Vozikis 1994) and could bridge the gap between intention and action, but should be tested further in future research.

This article is structured as follows. The theoretical foundation and hypotheses development are explained first, and then the research method and sample are addressed. The measurement and data analysis are then presented, followed by the findings, discussion of the findings and conclusions. Some recommendations for future research are made, and the limitations of the study are addressed.

\section{Theoretical foundation and hypotheses development}

According to Bandura (2001:6), human agency (as part of the social cognitive theory) refers directly to what is done intentionally. The human agency theory is used to explain the link between intentional entrepreneurial actions and the competencies of the agent. There are four core features of the human agency theory that must be explored, namely, intentionality, forethought, self-reactiveness and selfreflectiveness.

Intentionality represents a future action to be performed in the form of a provocative commitment (Bandura 2001:6). Intentional agency functions in such a way that intentions are at least partially fulfilled in one way or the other. An individual, who intends to pursue a business opportunity within the next 3 years, is defined as an intentional entrepreneur (Herrington \& Kew 2016:14; Nieman \& Nieuwenhuizen 2014:25). In this article, the nascent or existing entrepreneur is an agent that has the intention of starting a new venture in the near future.
Forethought is a temporal dimension of planning agency, as it is future-directed. An individual creates a possible course of action with the desired outcomes (Bandura 2001:7). When a potential entrepreneur becomes an intentional one (also referred to as a nascent or prospective entrepreneur), futuredirected pre-launch preparation tasks are performed (Giordano Martínez, Herrero Crespo \& Fernández-Laviada 2017:230; Nieman \& Nieuwenhuizen 2014:25, 33).

Self-reactiveness refers to the motivation and self-regulation of planned actions, and involves the ability to make plans and choices. The ability to realise future plans affects motivation (Bandura 2001:8). An individual can be motivated by necessity or opportunity to become an entrepreneur (Kelley et al. 2017:8; Nieman \& Nieuwenhuizen 2014:37). According to Bandura $(2001: 8,9)$, ability and competencies can affect aspirational pursuits and future goals. Entrepreneurial competencies can, thus, influence the motivation of entrepreneurs (nascent or prospective), who aspire and plan to work for themselves.

Self-reflectiveness refers to a self-examining action. The capability to reflect upon and evaluate one's actions, goals and plans is a core part of agency theory (Bandura 2001:10). The ability to 'see the bigger picture' is an entrepreneurial example of a self-reflectiveness competency (Nieman \& Nieuwenhuizen 2014:36).

Figure 1 illustrates a practical application of agency theory (intentionality, forethought, self-reactiveness and selfreflectiveness) to entrepreneurial intentions and capabilities. Human agency theory refers directly to (1) what is done intentionally and (2) the ability to realise that the future affects motivation (also referred to as competencies). The agency theory suggests that self-reactiveness, where entrepreneurial competencies are included, is influenced by intentions. At the same time, Bandura's social cognitive theory (Bandura 1986) suggests that an individual's surroundings cause behaviour, but behaviour also causes the surroundings. Bandura calls this concept a reciprocal determinism, where the world and the behaviour of persons

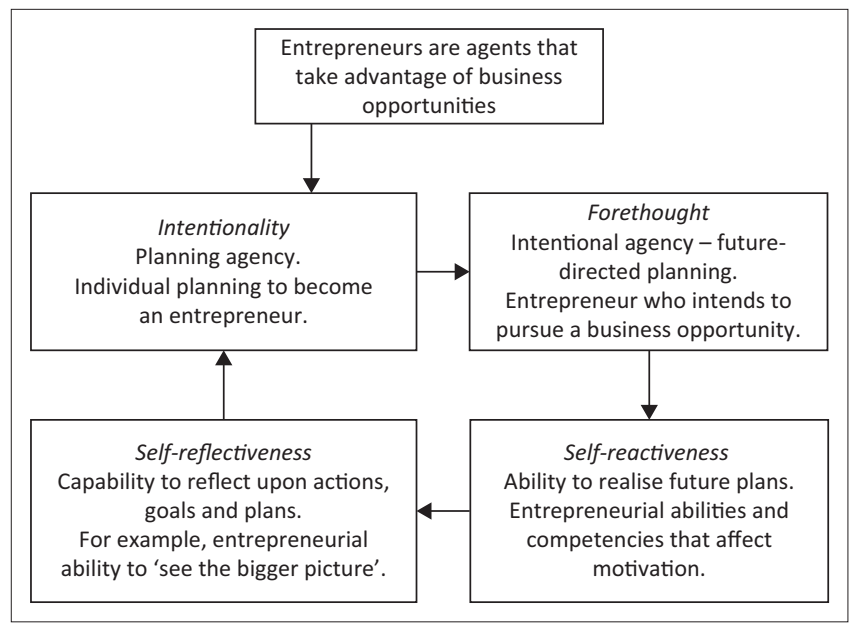

Source: Adapted from Bandura, A., 2001, 'Social cognitive theory: An agentic perspective', Annual Review of Psychology 52(1), 1-26. https://doi.org/10.1146/annurev.psych.52.1.1

FIGURE 1: Agency theory to link entrepreneurial intentions and competencies. 
are mutually caused. He believes that human conduct must be explained in terms of the reciprocal interaction between cognitive, behavioural and environmental determinants.

\section{The relationship between entrepreneurial intention and entrepreneurial competencies}

To test Thompson's (2009) notion that entrepreneurial intention can be treated as a predictor of outcome behaviours (such as opportunity recognition, entrepreneurial action, increased entrepreneurial performance and the actual start-up of businesses), we conducted a literature review on entrepreneurial intention (treated as the DV and a predictor). The literature search was conducted on entrepreneurial intention studies published in highly-rated entrepreneurial journals (impact factor of 1.0 or higher), such as the International Entrepreneurship and Management Journal, International Journal of Entrepreneurship and Small Business and Entrepreneurship as well as Entrepreneurship Theory and Practice. The keywords used were 'entrepreneurial intention', 'entrepreneurial intent', 'intention to start' 'dependent variable', 'independent variable', 'predictor' and 'bidirectional relationship,' and only studies that were published between 2000 and 2016 were included in the analysis. We identified 31 articles which confirmed that most studies treated entrepreneurial intention as a DV, except for Ibrahim and Abdullahi (2014) and Ibrahim and Lucky (2014), in which entrepreneurial intention was treated as a predictor of entrepreneurial skills, entrepreneurial orientation and environmental factors, as well as attitudes towards business formation as DVs. Ibrahim and Abdullahi (2014) found that a positive relationship exists between entrepreneurial intention as the IV and the attitude towards business formation as the DV. A positive relationship was also found between entrepreneurial intention as the IV and entrepreneurial skills, orientation and environmental factors as the DVs in the study by Ibrahim and Lucky (2014). At the same time, a positive relationship was found between entrepreneurial intention (DV) and entrepreneurial skills (IVs), which was also previously found by Fini et al. (2009) and Sookhtanlo et al. (2009), who affirmed that entrepreneurial skills are significantly related to entrepreneurial intention. However, in the studies by Ibrahim and Abdullahi (2014) and Ibrahim and Lucky (2014), these entrepreneurial skills were not tested individually but condensed as one skill by conducting regression analyses.

In a more recent study by Rezazadeh and Nobari (2018), a closer investigation was conducted into the antecedents (entrepreneurial attitude, complementarity and compatibility) and consequences (firm's agility, customer relationship management, learning, innovative and sensing capabilities) of cooperative entrepreneurship. The results provide evidence of the significant positive impact on partners' entrepreneurial attitude, complementarity and compatibility (as antecedents) of cooperative entrepreneurship, as well as the positive effects of cooperative entrepreneurship on firms' agility, customer relationship management, as well as learning, innovation and sensing capabilities (as consequences) (Rezazadeh \& Nobari 2018:479). An entrepreneur's education, training and experience are also seen as antecedents of entrepreneurial competencies
(Man et al. 2002:135). Findings by Morris et al. (2013) indicate that education plays an important role in the development process of an entrepreneur. These authors continue and emphasise that it is imperative to provide key building blocks or scripts (i.e. norms, values and rules guiding desirable behaviour) and constructing experiences through which students can use these scripts, gain feedback, confirm or disconfirm their assumptions and understandings. In turn these experiences and understandings should mould their attitudes and behaviours into competencies. In this article, we discuss and test the bidirectional relationships between entrepreneurial intention and the individual entrepreneurial competencies, as the Theory of Planned behaviour (Ajzen 1991) underpins the fact that entrepreneurial intention can predict behaviour and that behaviour is embedded in entrepreneurial competencies (Kiggundu 2002).

\section{Individual entrepreneurial competencies}

Several scholars, such as Man et al. (2002), Baum (1994) and Hazlina Ahmad et al. (2010), identified entrepreneurial competencies that nascent entrepreneurs' need, namely, opportunity recognition, building relationship, innovativeness, operational, human, strategic, commitment to business, learning and personal strength competencies. The strongest competencies that Baum (1994) identified that existing entrepreneurs should have when growing the venture are the following: self-efficacy, technical skills, personal marketing skills, innovation and a passion for work. The weaker competencies in this regard were highlighted as related to the venture's vision, organisational skills, growth objectives, skills of identification of opportunities and experiences in running the business. Morris et al. (2013) built on the work of previous scholars and used the Delphi-technique to identify 13 necessary competencies that is believed to lead to entrepreneurial action, namely, opportunity recognition, opportunity assessment, risk management, conveying a compelling vision, tenacity or perseverance, creative problem-solving, resource leveraging, guerrilla skills, value creation through innovation, maintain focus yet adapt, resilience, self-efficacy, and building and using networks. For this article, only eight of the individual entrepreneurial competencies, as identified by Morris et al. (2013), were tested as explained in the factor analysis section.

The next part of the literature review is divided into two sections: (1) support in the literature for a bidirectional relationship between entrepreneurial intention and entrepreneurial competencies and (2) the lack of support in the literature for a bidirectional relationship between entrepreneurial intention and entrepreneurial competencies.

\section{Support in the literature for a bidirectional relationship between entrepreneurial competencies and entrepreneurial intentions}

\section{Opportunity recognition}

Morris et al. (2013:358) define opportunity recognition as the capacity to perceive changed or overlooked possibilities in the environment, which may represent potential sources of 
profit or return to a venture. In earlier studies, opportunity recognition or identification has been referred to as entrepreneurial intention. For example, Shaver and Scott (1991) state that entrepreneurs have a type of motivation (i.e. entrepreneurial intent) that makes the entrepreneurial process result in opportunity realisation. Likewise, Krueger et al. (2000) also found that the opportunity identification process is an intentional process, which offers a means to better explain and predict entrepreneurship. The role of the entrepreneur in opportunity search and identification activities is controversial because intention models posit that entrepreneurs intend to be entrepreneurs before they locate opportunities (Krueger 1993). In later studies, it was proposed that individuals with higher entrepreneurial intention have the ability and competency to identify opportunities (Volery et al. 2013). Krueger (1993) associated self-efficacy with opportunity recognition, and Short et al. (2010) later established that self-efficacy is directly related to entrepreneurial intention, thus deducing that opportunity recognition and entrepreneurial intention have a bidirectional relationship.

\section{Opportunity assessment}

Although opportunity recognition is believed to be the first step in an entrepreneurial process, opportunity exploitation is thought to be the second step, which may start in the nature of the opportunity and individual differences (Shane \& Venkataraman 2000), or simply in the decision of someone to act (Alvarez \& Barney 2007). Entrepreneurial intention is seen as the mental force that realises the value of a new business opportunity (Cha \& Bae 2010:37). Morrison, Breen and Ali (2003:423) note that intention, ability and opportunity are linked intrinsically, and business growth is unlikely to be achieved should one be missing or be unduly weak. Without intention driven by entrepreneurial vision and energy, an opportunity cannot be assessed and opportunities will not be translated into business growth (Morrison et al. 2003). Thus, the preceding literature suggests that a bidirectional relationship is possible.

\section{Conveying a compelling vision}

Morrison et al. (2003:358) describe conveying a compelling vision as the ability to provide an image of a future organisational state and to portray that image in a manner that empowers followers to enact it'. According to Parente and Feola (2013), entrepreneurial intention plays a role for a potential venture to be taken forward, predicting a vision that the entrepreneur has created in his or her mind. Through conveying the entrepreneurs' vision, the entrepreneurial intention initiatives new venture's innovation processes and helps to build a new venture (Cha \& Bae 2010).

\section{Creative problem-solving}

Creativity is a common manifestation of entrepreneurship and is well documented in the existing literature (Becherer, Mendenhall \& Eickhoff 2008:5). According to Schein and Schein (1978:149), typologies of entrepreneurially-oriented people portray them as obsessive with the need to create and solve problems. Knowing that entrepreneurs have a higher level of entrepreneurial intentions than non-entrepreneurs, it can be deduced that higher levels of entrepreneurial intentions are present during problem-solving (McMullen \& Shepherd 2006). Zampetakis and Moustakis (2006) presented a preliminary model which links creativity with entrepreneurial intention.

\section{Value creation through innovation}

Morris et al. (2013:358) describe value creation as the 'capabilities of developing new products, services, and/or business models that generate revenues exceeding their costs and produce sufficient user benefits to bring about a fair return'. Although innovativeness is found to be one of the factors affecting students' entrepreneurial intention, it also adds economic value in terms of new product development, identifying new processes and exploiting new markets ( $\mathrm{Al}$ Mamun et al. 2016:126). Groves et al. (2008) found that successful entrepreneurs that exhibited high levels of entrepreneurial intention showed significant levels of nonlinear thinking. It is not surprising then that innovation has been indicated to be a trigger of entrepreneurial intentionaction. Similarly, many other scholars, such as Gorman, Hanlon and King (1997), Feldman and Bolino (2000) and Sternberg (2004), propose that individuals with a strong innovation anchor and the capacity to think outside the box are motivated to become self-employed. The innovativeness of a planned venture is, thus, important because an intention to be innovative is a leading indicator of higher performance in small and medium enterprises (SMEs) (Kundu \& Katz 2003:31). Cha and Bae (2010) suggest that entrepreneurial intention may be considered as the internal driving force behind value creation because of its position at the centre of the underlying layers of the emergent process of opportunity realisation. Based on the theory by Ajzen (1991), which focuses on the intention to engage in a behaviour (e.g. the intention to adopt innovations), the predictive power of innovativeness is based on entrepreneurs' intention to adopt innovation (Marcati, Guido \& Peluso 2008:1583).

\section{Perseverance}

In the identification of entrepreneurial competencies, Morris et al. (2013:358), who use tenacity and perseverance interchangeably, describe perseverance as 'the ability to sustain goal-directed action and energy when confronting difficulties and obstacles that impede goal achievement'. There is an underlying assumption in the literature that perseverance is one of the motivating factors necessary for entrepreneurial intention because it acts as an inner drive towards a given goal (Gibson et al. 2009). However, in a study by Urban and Richard (2015:264), the relationship between perseverance and entrepreneurial intention showed that, even though people may have low levels of perseverance, they may still have high levels of entrepreneurial intention. Pendame (2014:39) and Mangundjaya (2009) also found no significant relationship between perseverance and entrepreneurial intention. Although mixed results are observed, there is still evidence of a positive relationship between entrepreneurial intention and perseverance. 
The literature shows support or at least partial support regarding the preceding individual competencies. However, these competencies have not been tested in a bidirectional relationship with entrepreneurial intention. Therefore, it justifies the following hypothesis statements:

H1: There is a positive bidirectional relationship between entrepreneurial intention and the following entrepreneurial competencies:

- H1a: Opportunity recognition

- H1b: Opportunity assessment

- H1c: Conveying a compelling vision

- H1d: Creative problem-solving

- H1e: Value creation through innovation

- H1f: Perseverance.

\section{Lack of support in the literature for a bidirectional relationship between entrepreneurial competencies and entrepreneurial intentions}

\section{Self-efficacy}

It is well known that self-efficacy is a predictor of entrepreneurial intention (Bronowitz \& Rader 2008; Kolvereid 1996; Pfeifer et al. 2016; Wakkee et al. 2010), as well as a moderator in the relationship between entrepreneurial intention and action (Boyd \& Vozikis 1994). As self-efficacy is defined as the perceived ability to perform a behaviour (or sequence of behaviours), it is expected that entrepreneurial intention will be a strong predictor of self-efficacy (Boyd \& Vozikis 1994); however, this could not be confirmed in the literature and is therefore worthy of further investigation.

\section{Building and using networks}

Building and maintaining diverse social networks is a behavioural skill identified after interviewing innovative entrepreneurs who had engaged in this behavioural skill more frequently than typical executives (Dyer, Gregersen \& Christensen 2008:327). Social networking plays an imperative role in developing entrepreneurial intentions among entrepreneurs and is the main reason for successful business (Kefela 2011; Zafar, Yasin \& Ijaz 2012). Taylor and Thorpe (2004) seem to agree with this, adding that networks gained through previous work experience can positively impact the entrepreneurial intention of students. Fayolle et al. (2015) contribute to the entrepreneurial intention and competencies relationship by adding that the greater an entrepreneur's network orientation, the higher the level of competence development and the stronger the positive relationship between entrepreneurial intention and competencies will be (Fayolle et al. 2015). However, no support could be found that entrepreneurial intention and the ability to build and use networks can influence each other.

Although support for the relationships between self-efficacy and the ability to build and use networks with entrepreneurial intention could not be confirmed in the literature, this article explores the possibility of a bidirectional relationship between entrepreneurial intention and these competencies, and model fit is determined later in the article. Based on the preceding literature review, it is hypothesised that:

H2: There is no bidirectional relationship between entrepreneurial intention and the following entrepreneurial competencies:

- H2a: Self-efficacy

- H2b: Building and using networks.

\section{Methodology Study area}

This quantitative research was carried out by means of a structured research questionnaire (survey) that was e-mailed (1450 respondents) or personally distributed (330 respondents) at various South African organisations such as the University of Pretoria (tertiary institution), National Youth Development Agency (government organisation) and the Gauteng Enterprise Propeller (non-government organisation). The final realised sample was 342, which represents a response rate of $19 \%$. Potential heterogeneity bias, as a result of the industry in which an individual operates, was tested by conducting statistical difference testing. No statistically significant differences (all $p>0.05$ ) between individuals from different industries were found for all the latent constructs tested.

\section{Structured research questionnaire}

The questionnaire was divided into three sections. Section A consisted of a combination of open- and closed-ended questions that represent demographic and venture life cycle information. These include gender, race, age, highest level of education, business sectors and length of time the business has been in operation. Section B captured 10 statements that measured the Individual Entrepreneurial Intention Scale, which was developed by Thompson (2009). A fourpoint Likert scale was used where 1 = very untrue, 2 = untrue, $3=$ true and $4=$ very true. This section included statements on the intent to set up a business in the future, as well as business opportunities and resources to start a business. In Thompson's study, the scale's Cronbach's alpha coefficient of internal reliability was 0.89 for 450 randomly selected convenient respondents; 0.84 for 160 student respondents and 0.86 for an international sample of 947 . Hence, the scale seemed to have acceptable internal consistency (reliability). Furthermore, the Cronbach's alpha coefficient of internal consistency (reliability) proved to be 0.668 on the original 10-item scale as used by Thompson (2009); hence, the scale seemed to have acceptable internal reliability in this study

In Section C, the respondents were asked to answer selfperception questions on how the statements applied to them regarding their individual entrepreneurial competencies. This was done by including the Entrepreneurial Competency Scale developed by Morris et al. (2013:356). However, it was adapted to fit within the developing country context, which resulted in eight competencies that were tested in 51 statements using a five-point Likert scale, in which 
1 = strongly disagree, 2 = disagree, $3=$ neutral, $4=$ agree and 5 = strongly agree. In the Morris et al.'s (2013) study, the Cronbach's alpha coefficient was tested individually for each of the competencies and varied between 0.62 as the lowest and 0.97 as the highest.

\section{Sampling method and survey}

Of the total sample, 219 respondents (64\%) were categorised in the 'nascent entrepreneur' sub-sample, and as 123 respondents (36\%) owned a business, they were labelled as part of the 'existing entrepreneur' sub-sample.

We adopted the sampling frame used by Davidsson and Honig (2003) to divide the sample. An individual was considered a nascent entrepreneur if he or she had initiated at least one gestation activity for a current, independent startup by the time of the measurement. These gestation activities included having prepared a business plan; developed an idea; recognised an opportunity; developed a new product or service; gathered other resources to start a business and so on. Some existing business gestation activities included whether money had been invested; if the firm was already a legal entity and so on (Carter, Gartner \& Reynolds 1996; Davidsson \& Honig 2003).

\section{Data analysis}

Confirmatory factor analysis was used first to determine an acceptable fit of the data to the model for entrepreneurial intention. In the case of entrepreneurial competencies, which were adapted from the original instrument, exploratory factor analysis (EFA) was performed to determine the dimensionality of each. Thereafter, structural equation modelling (SEM) was conducted to determine whether entrepreneurial intention as the IV is a statistical significant predictor of the eight competencies used as DVs. Structural equation modelling was used to test the paths between entrepreneurial intention as an IV and the eight competencies (DVs) simultaneously in one model. An acceptable model fit is indicated by a chi-square probability greater than or equal to 0.05 . Furthermore, an acceptable model fit is specified by a comparative fit index (CFI) with a value of 0.90 or greater, Tucker-Lewis Index (TLI) with a value of 0.90 or greater and an incremental fit index (IFI) value of 0.90 or greater ( Hu \& Bentler 1999:1).

\section{Findings \\ The validity and reliability of the scales}

The result of the confirmatory factor analysis indicated a nonacceptable fit for entrepreneurial intention (RMSEA $=0.096$; $\mathrm{IFI}=0.750, \mathrm{CFI}=0.744$ and $\mathrm{CMIN} / d f=4.172)$. Exploratory factor analysis was subsequently conducted, using principal axis factoring extraction and Promax rotation, to determine the dimensionality of entrepreneurial intention and each of the entrepreneurial competencies. The required minimum acceptable level of consistency is 0.7 for all reported reliability coefficients (Nunnally 1978) when using existing instruments.
However, in exploratory research, 0.6 is considered acceptable (Bagozzi \& Yi 1988:80; Hair et al. 2010). This is confirmed by various entrepreneurship scholars such as Farrington et al. (2012) and Antonites and Nonyane-Mathebula (2012), who conducted their research on samples from developing countries such as South Africa and accepted alpha values of 0.6.

The Harmon test for common method bias was carried out, and the results of the test indicated that no single factor solution emerged for the entrepreneurial intention construct and the first factor accounts for only $27 \%$ of the explained variance versus $24 \%$ for the remaining two factors (eigenvalues less than 1). Therefore, no common method bias exists regarding entrepreneurial intention.

The Cronbach's alpha values of two of the three factors were below the threshold of 0.6. Six items loaded on the remaining factor, with a Cronbach's alpha values of 0.610 and 0.668 on the original 10-item scale, as used by Thompson (2009).

\section{Factor analysis: Entrepreneurial competencies}

Exploratory factor analyses were conducted to validate the scales. Overall, these analyses indicated that of the 12 competencies, 10 indicated uni-dimensionality of the competency, and two of them, value creation and building and using networks, resulted in two sub-factors each. A total of two items were eliminated as they did not contribute to a simple factor structure and failed to meet the minimum criteria of having a primary loading of 0.4 or above, and/or cross-loading of 0.3 and above.

Table 1 presents the reliability analysis on the constructs that were retained for further analysis. No substantial increases in alpha for any of the scales could have been achieved by eliminating more items. Overall, these analyses indicated that 10 competencies (distinct factors) were internally consistent. Therefore, 10 factors were included for further testing.

The EFAs confirmed uni-dimensionality in opportunity recognition, opportunity assessment, risk management,

TABLE 1: Entrepreneurial competencies factor structure and measures.

\begin{tabular}{llc}
\hline Factors & Sub-factors & Cronbach's alpha \\
\hline Opportunity recognition & - & 0.649 \\
Opportunity assessment & - & 0.650 \\
Risk management or mitigation & - & 0.341 \\
Conveying a compelling vision & - & 0.677 \\
Tenacity or perseverance & Consistency of interest & 0.414 \\
& Persistence of action & 0.672 \\
Creative problem-solving or & - & 0.776 \\
imaginativeness & & \\
Resource leveraging & - & 0.442 \\
Value creation through innovation & Challenge status quo & 0.739 \\
& Observing customer usage & 0.703 \\
Maintain focus yet adapt & - & 0.461 \\
Resilience & - & 0.413 \\
Self-efficacy & - & 0.756 \\
Building and using networks & Maintain contacts & 0.872 \\
& Participate in community & 0.716 \\
\hline
\end{tabular}


conveying a compelling vision, tenacity or perseverance, creative problem-solving, resource leveraging, value creation, maintaining focus, resilience, self-efficacy, and building and using networks.

Factor-based scores were subsequently calculated as the mean score of the variables included in each factor. Factors with Cronbach's alphas lower than the threshold of 0.6 , such as risk management (0.341); perseverance (sub-factor: consistency of interest -0.414$)$; resource leveraging (0.442); maintain focus yet adapt (0.641) and resilience (0.413), were excluded from the analyses that follow.

\section{The demographic profile of respondents}

The nascent and existing samples have been explained and most of the existing entrepreneur respondents were in the business services, information technology and manufacturing sectors. Thirty-five per cent of the respondents completed at least a secondary school-level education, with $24 \%$ having obtained a tertiary qualification (university degree). The total sample consisted of $43 \%$ female and $57 \%$ male respondents and most of the respondents were categorised in the 21-35 age group (mean value of 30.42 ).

\section{Structural equation modelling results}

Based on the literature review, the relationships between all eight entrepreneurial competencies and entrepreneurial intention were determined. Figure 2 presents a graphical illustration of the hypothesised structural model whereby the relationship between entrepreneurial intention and the eight entrepreneurial competencies is tested. As indicated in the previous section, both value creation and building and using networks resulted in two sub-factors each.

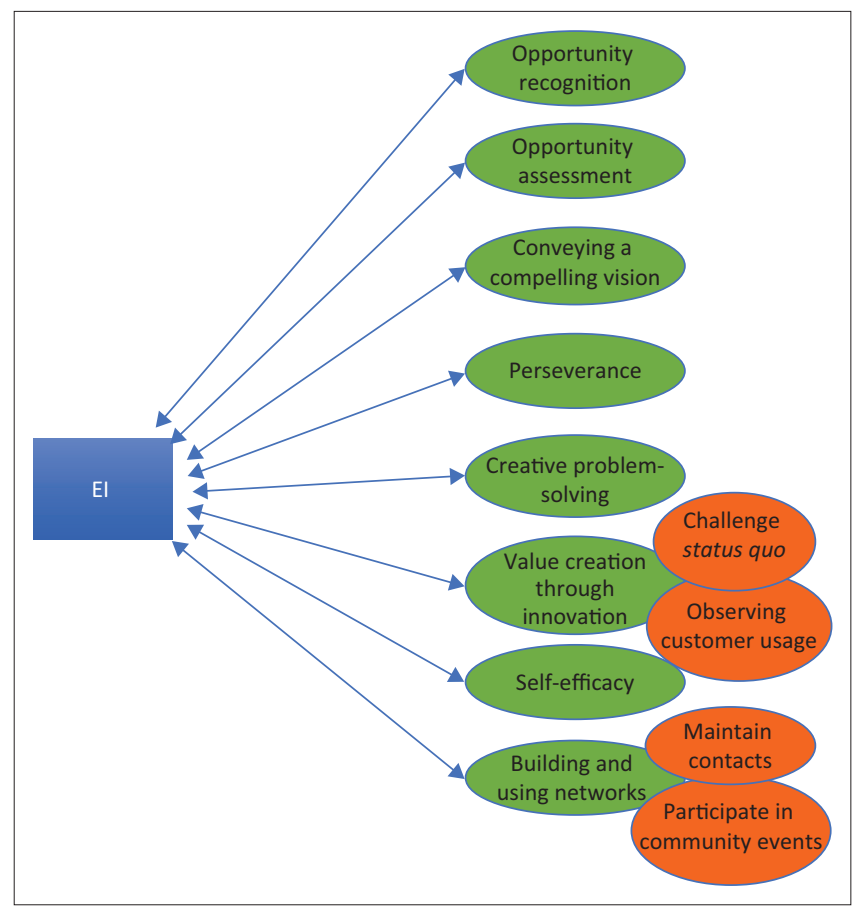

FIGURE 2: Hypothesised structural model.
In Table 2, it is evident that, for model 1, the chi-square mean/ degree of freedom $(\mathrm{CMIN} / d f)$ value of 1.912 is less than the recommended value of 3.00. Comparative Fit Index and IFI values for this model are equal or more than the recommended 0.90 and TLI almost 0.90 . An acceptable model fit is indicated by an RMSEA value of 0.08 or less (Hu \& Bentler 1999:1). In model 1, the 0.052 RMSEA value is less than the required 0.08; therefore, this model is deemed an acceptable model fit. Because of the overall model fit, this article confirms that a bidirectional relationship is evident between entrepreneurial intention and the set of entrepreneurial competencies tested in the model. The results of the standardised regression weights (path coefficients) indicated the statistical significance and strength of the individual relationships.

Table 3 presents the direction and strength of the relationships (correlations) between the variables; the associated significance and the strength thresholds, as confirmed by Pallant (2001), are used. These strength thresholds are $0-0.2=$ weak; $0.2-0.4=$ modest; $0.4-0.6=$ moderate; $0.6-0.8=$ moderately strong and $0.8-1.0=$ strong. The findings in Table 3 point out that a moderate positive bidirectional relationship is evident between entrepreneurial intention and self-efficacy (0.516) at a significance level of $p<0.001$. This relationship is the strongest and most significant and is also confirmed in the literature by Bronowitz and Rader (2008), Kolvereid (1996), Pfeifer et al. (2016) and Wakkee et al. (2010), who state that self-efficacy is a predictor of entrepreneurial intention. However, the inverse relationship has not been established in previous research, and the finding in this article confirms our notion that a bidirectional relationship exists between these constructs and that they influence each other.

Entrepreneurial intention has a modest positive bidirectional relationship with the following entrepreneurial competencies:

TABLE 2: Goodness-of-fit indices (model 1).

\begin{tabular}{lccccc}
\hline \multicolumn{1}{c}{ Model } & CMIN/df & IFI & TLI & CFI & RMSEA \\
\hline Goodness-of-fit indices (model 1) & 1.912 & 0.907 & 0.885 & 0.905 & 0.052 \\
Acceptable threshold levels & $<3.00$ & $>0.90$ & $>0.90$ & $>0.90$ & $<0.08$ \\
\hline
\end{tabular}

$\mathrm{CMIN} / d f$, chi-square mean/degree of freedom; IFI, incremental fit index; TLI, Tucker-Lewis index; CFI, comparative fit index; RMSEA, root mean square error of approximation.

TABLE 3: Standardised regression weights (path coefficients).

\begin{tabular}{|c|c|c|}
\hline \multicolumn{2}{|c|}{ Relationship variables } & \multirow{2}{*}{$\begin{array}{l}\text { Standardised regression weights } \\
\qquad 0.237^{* *}\end{array}$} \\
\hline $\mathrm{EI} \leftrightarrow$ & Opportunity recognition & \\
\hline $\mathrm{EI} \leftrightarrow$ & Opportunity assessment & 0.085 \\
\hline $\mathrm{EI} \leftrightarrow$ & Conveying a compelling vision & $0.233^{* *}$ \\
\hline $\mathrm{EI} \leftrightarrow$ & Perseverance & $0.206^{*}$ \\
\hline $\mathrm{EI} \leftrightarrow$ & Creative problem-solving & 0.078 \\
\hline $\mathrm{EI} \leftrightarrow$ & $\begin{array}{l}\text { Value creation through innovation } \\
\text { (challenge status quo) }\end{array}$ & -0.021 \\
\hline $\mathrm{El} \leftrightarrow$ & $\begin{array}{l}\text { Value creation through innovation } \\
\text { (observing customer usage) }\end{array}$ & $0.222 * *$ \\
\hline $\mathrm{EI} \leftrightarrow$ & Self-efficacy & $0.516 * * *$ \\
\hline $\mathrm{EI} \leftrightarrow$ & $\begin{array}{l}\text { Building and using networks } \\
\text { (maintain contacts) }\end{array}$ & -0.037 \\
\hline $\mathrm{EI} \leftrightarrow$ & $\begin{array}{l}\text { Building and using networks } \\
\text { (participate in community events) }\end{array}$ & -0.095 \\
\hline
\end{tabular}


opportunity recognition (0.237); conveying a compelling vision (0.233) and value creation through innovation (subfactor: observing customer usage 0.222 ) at a significance level of $p<0.01$. This is confirmed in the literature by Parente and Feola (2013:159), who state that entrepreneurial intention plays a role in the probability that a potential venture will be taken forward according to a predicted vision that the entrepreneur has created in his or her mind. Cha and Bae (2010:40) also found that through conveying the entrepreneurs' vision, entrepreneurial intention initiates new innovation processes and helps build a new venture. The findings in Table 3, furthermore, indicate that entrepreneurial intention has weak positive bidirectional relationships with perseverance (0.206) at a significant level of $p<0.05$. Mixed findings were observed in the literature review regarding the relationship between perseverance and entrepreneurial intention. Our findings confirm a bidirectional relationship although weak, and disagree with the findings of Pendame (2014:39) and Mangundjaya (2009), who found no significant relationship between perseverance and entrepreneurial intention. Regarding the relationship between entrepreneurial intention and opportunity assessment (0.085) and creative problem-solving (0.078), these relationships are also weak and positive, but not significant. It is an unexpected finding as a significant bidirectional relationship was expected between these constructs, as the literature review also suggests that a bidirectional relationship is possible (Cha \& Bae 2010; McMullen \& Shepherd 2006).

A weak, negative relationship is observed between entrepreneurial intention and building and using networks (sub-factor: maintain contacts -0.037 and sub-factor: participate in community events -0.095) and the relationships are not significant. These findings agree with most of the previous scholars (Boyd \& Vozikis 1994; Fayolle et al. 2015), which stated that networking and entrepreneurial intention have been linked; however, a bidirectional relationship cannot be confirmed. Entrepreneurial intention also had a weak negative relationship with value creation through innovation (sub-factor: challenge status quo -0.021). Although Ajzen's theory (1991), which focuses on the intention to engage in a behaviour (e.g. the intention to adopt innovations), suggests that the predictive power of innovativeness is based on entrepreneurs' intention to adopt innovation (Marcati et al. 2008:1583), a bidirectional relationship could not be confirmed in this article.

\section{Discussion of the findings}

Structural equation modelling was conducted to determine whether entrepreneurial intention and any of the individual entrepreneurial competencies have a bidirectional relationship whereby the constructs influence each other. An acceptable model fit is confirmed in this article as the fit indices (CFI and IFI) are greater than the recommended 0.90 and RMSEA $=0.052$. As far as could be determined, this is the first study that tests the bidirectional relationship between these constructs. Furthermore, the strength and significance of the individual relationships were tested, and self-efficacy has the most significant relationship (moderate and positive) with entrepreneurial intention. Entrepreneurial intention has also a modest positive significant bidirectional relationship with opportunity recognition, conveying a compelling vision, value creation (sub-factor: observing customer usage) and perseverance. At the same time, weak positive relationships were observed between entrepreneurial intention and opportunity assessment, as well as with creative problemsolving, yet these relationships were not significant. Lastly, weak negative relationships were evident between entrepreneurial intention and building and using networks (both sub-samples) and value creation through innovation (challenge status quo). As previous research did not test the bidirectional relationships between entrepreneurial intention and these competencies, it can be confirmed that in this article the following hypotheses were either supported or not supported:

H1: There is a positive bidirectional relationship between entrepreneurial intention and the following entrepreneurial competencies:

- H1a: Opportunity recognition (supported)

- H1b: Opportunity assessment (not supported)

- H1c: Conveying a compelling vision (supported)

- H1d: Creative problem-solving (not supported)

- H1e: Value creation through innovation (sub-factor: observing customer usage - supported) (sub-factor: challenge status quo - not supported)

- H1f: Perseverance (supported).

H2: There is no bidirectional relationship between entrepreneurial intention and the following entrepreneurial competencies:

- H2a: Self-efficacy (not supported)

- H2b: Building and using networks (both sub-factors supported).

Therefore, when testing the individual entrepreneurial competencies by means of the standard regression weights (path coefficients), five of the individual entrepreneurial competencies had significant bidirectional relationships with entrepreneurial intention. They are opportunity recognition, conveying a compelling vision, value creation through innovation (observing customer usage), perseverance and self-efficacy. The findings in this article indicate that although previous research found that self-efficacy is a predictor of entrepreneurial intention (Bronowitz \& Rader 2008; Kolvereid 1996; Pfeifer et al. 2016; Wakkee et al. 2010), this article determined that these two constructs influence each other. Mixed results are evident for value creation through innovation, as entrepreneurial intention did have a modest positive relationship with one sub-factor (observing customer usage) and a weak, non-significant, negative relationship with the other sub-factor (challenge status quo). The findings could not confirm a bidirectional relationship between entrepreneurial intention and the following entrepreneurial competencies: opportunity assessment, creative problemsolving, value creation through innovation (challenge status $q u o$ ) and both sub-factors of building and using networks. Although these entrepreneurial competencies did not have a bidirectional relationship with entrepreneurial intention, 
they might have a one-directional relationship and should be tested further in future research.

\section{Conclusion}

Although many scholars focused on the predictors of entrepreneurial intention (Autio et al. 2001; Krueger 1993; Reitan 1996), in this article we test Thompson's (2009) notion that entrepreneurial intention can be used as a predictor of certain outcomes and therefore determined the bidirectional relationship with entrepreneurial competencies. The importance of establishing a bidirectional relationship between these constructs can be beneficial to educators and policy-makers who develop entrepreneurial training and education programmes, as a bidirectional relationship might increase the outcomes of business start-up and entrepreneurial action. The social cognitive theory and human agency theory established a link between entrepreneurial competencies and intentions on a psychological level (Biraglia \& Kadile 2017; Bird 1988; Krueger 1993; Zhao \& Seibert 2006). It is argued that this link should be tested by measuring entrepreneurs at different stages of the entrepreneurial venture life cycle. Through SEM we establish that a bidirectional relationship is evident between entrepreneurial intention and the set of entrepreneurial competencies tested in the model. The results of the standardised regression weights (path coefficients) indicated the statistical significance and strength of the individual relationships, and entrepreneurial intention has the strongest significant bidirectional relationship with self-efficacy.

The contribution of this article is threefold: firstly, it answers the call by Thompson (2009:670) to test entrepreneurial intention not only as a DV but also as the inverse relationships and therefore contributes to the entrepreneurial intention construct and intention models. The findings in this article present the possibility of testing other bidirectional relationships with entrepreneurial intention. By challenging the existing body of knowledge in which entrepreneurial intention was previously only tested as a DV, it might encourage other scholars to explore new avenues of testing entrepreneurial intention in different settings, contexts and countries. According to Krueger (2017:59), one needs to take a second look at how intentions are modelled and the construct of intention itself. As we recall, all these models are grounded in the logic of a formative model, which is that there are antecedents that combine to form the target variable (Krueger 2017:59). In an early study by Liska (1984:68), it was suggested that the 'antecedents' may instead comprise a reflective model. Bagozzi and Warshaw (1990) also forced several changes in modelling intentions effectively, especially if one seeks to predict and not just explain. Secondly, educators and policy-makers interested in promoting entrepreneurship may pay attention to the individual entrepreneurial competencies that have a bidirectional relationship with entrepreneurial intention. The competencies with the positive and significant relationships (self-efficacy, opportunity recognition, conveying a compelling vision, value creation through innovation - sub-factor observing customer usage and perseverance) can be included in startup training programmes for potential and nascent entrepreneurs to enhance business start-up. Therefore, to upskill 'novice' entrepreneurs into an 'expert', a more informed intent (Krueger 2017:66) of entrepreneurs with the required competencies that leads to the growth phase of the venture life cycle is needed. For example, although entrepreneurs at the different stages of the entrepreneurial life cycle should be able to find this study beneficial, the ability to compare one's competencies with those of existing entrepreneurs could provide potential, nascent and start-up entrepreneurs with the understanding that they should acquire individual entrepreneurial competencies, such as opportunity recognition, perseverance, self-efficacy, and value creation, if they wish to make the leap towards owning a successful business venture. Lastly, previous work confirmed that self-efficacy is a strong predictor of entrepreneurial intention (Bronowitz \& Rader 2008; Kolvereid 1996; Pfeifer et al. 2016; Wakkee et al. 2010), as well as a moderator in the relationship between entrepreneurial intention and action (Boyd \& Vozikis 1994:73). A positive significant bidirectional relationship is found in this article between entrepreneurial intention and self-efficacy. Educators, policy-makers and academics can use this finding and adapt their entrepreneurial training programmes to ensure that self-efficacy and entrepreneurial intention are taught simultaneously as these constructs influence each other and can enhance the outcomes (business start-up or performance) of such a training programme. This could bridge the gap between intention and action, but should be tested in future research.

\section{Limitations and future research avenues}

No study is without limitations. This article investigates nascent and existing entrepreneurs only. As suggested by Mitchelmore and Rowley (2010:104), entrepreneurial competencies should be explored at different stages of the entrepreneurial venture, as different competencies are needed at each stage. Future research can include potential, start-up and even serial entrepreneurs, and draw comparisons between the competencies acquired at the different stages. As this study sets the stage for bidirectional relationships with entrepreneurial intention, future studies can investigate other outcomes of entrepreneurial intention, such as entrepreneurial action, performance and other behaviours. Furthermore, future studies should test whether the bidirectional relationship between entrepreneurial intention and entrepreneurial competencies does, indeed, enhance or lead to the outcomes of business start-up and entrepreneurial action. The research in this article is carried out in a single period, and it is suggested that future research should conduct a longitudinal study over a 2-year period to measure whether high levels of entrepreneurial intention and entrepreneurial competencies may lead to entrepreneurial action (start-up) and business success. In the same sense, the model in this article can be tested, where entrepreneurial 
competencies are treated as mediators and/or moderators in the relationship between entrepreneurial intention and action, as well as between entrepreneurial intention and business success.

Scholars should take advantage of more rigorous experimental methodologies, such as neuroscience (neuroentrepreneurship), to better understand the deeper structures of entrepreneurial competencies and intention. Neuroscience could provide new ways to conceptualise and measure important facets of entrepreneurial decision-making (Krueger \& Welpe 2014:6). We acknowledge that the set of entrepreneurial competencies used in this study is not exclusive of other competencies and that there might be competencies that are not included here. It is also advised that the antecedents of entrepreneurial intention and entrepreneurial competencies be investigated in more detail. As the sample in this article focused on South Africa (developing country context), it is worthy to investigate the bidirectional relationship between entrepreneurial intention and self-efficacy in developed countries, as well as including a different sampling frame. It is acknowledged that mediators and moderators were not included in the present study, and future studies could include demographic variables, as well as other antecedents, to further test the bidirectional relationship between entrepreneurial intention and self-efficacy.

\section{Acknowledgements Competing interests}

The authors declare that they have no financial or personal relationship(s) that may have inappropriately influenced them in writing this article. The views and opinions expressed in this article are those of the authors and do not necessarily reflect the official policy or position of any affiliated agency of the authors

\section{Author's contributions}

A.T. collected the data and contributed to the literature review and methodology sections. M.B. conducted the analysis and prepared the literature review and discussion and conclusion sections.

\section{References}

Ahmad, N.H., Halim, H.A. \& Zainal, S.R.M., 2010, 'Is entrepreneurial competency the silver bullet for SME success in a developing nation', International Business Management 4(2), 67-75. https://doi.org/10.3923/ibm.2010.67.75

Ajzen, I., 1991, 'The theory of planned behavior', Organizational Behavior and Human Decision Processes 50(2), 179-211. https://doi.org/10.1016/0749-5978(91)90020-T

Al Mamun, A., Nawi, N.B.C. \& Shamsudin, S.F.F.B., 2016, 'Examining the effects of entrepreneurial competencies on students' entrepreneurial intention Mediterranean Journal of Social Sciences 7(2), 119. https://doi.org/10.5901/ mjss.2016.v7n2p119

Alvarez, S.A. \& Barney, J.B., 2007, 'Discovery and creation: Alternative theories of entrepreneurial action', Strategic Entrepreneurship Journal 1(1-2), 11-26. https:// doi.org/10.1002/sej.4

Antonites, A.J. \& Nonyane-Mathebula, B.T., 2012, 'Engineers as entrepreneurs: Entrepreneurial orientation of engineers in South Africa', South African Journal of Industrial Engineering 23(1), 1-17.

Autio, E., Keeley, R.H., Klofsten, M., Parker, G.G.C. \& Hay, M., 2001, 'Entrepreneurial intent among students in Scandinavia and in the USA', Enterprise and Innovation Management Studies 2(2), 145-160. https://doi.org/10.1080/14632440110094632
Bagozzi, R.P. \& Yi, Y., 1988, 'On the evaluation of structural equation models', Journal of the Academy of Marketing Science 16(1), 74-94. https://doi.org/10.1007/ of the Academ
BF02723327

Bagozzi, R. \& Warshaw, P., 1990, 'Trying to consume', Journal of Consumer Research 17(2), 127-140. https://doi.org/10.1086/208543

Bandura, A., 1986, Social foundations of thought and action: A social cognitive theory, Prentice Hall, Englewood Cliffs, NJ.

Bandura, A., 1989, 'Human agency in social cognitive theory', American Psychologist 44(9), 1175-1184. https://doi.org/10.1037/0003-066X.44.9.1175

Bandura, A., 2001, 'Social cognitive theory: An agentic perspective', Annual Review of Psychology 52(1), 1-26. https://doi.org/10.1146/annurev.psych.52.1.1

Baum, J.R., 1994, 'The relation of traits, competencies, vision, motivation, and strategy to venture growth', PhD dissertation, University of Maryland, College Park, MD.

Becherer, R.C., Mendenhall, M. \& Eickhoff, K.F., 2008, 'Separated at birth: An inquiry on the conceptual independence of the entrepreneurship and the leadership constructs', New England Journal of Entrepreneurship 11(2), 4. https://doi. org/10.1108/NEJE-11-02-2008-B002

Biraglia, A. \& Kadile, V., 2017, 'The role of entrepreneurial passion and creativity in developing entrepreneurial intentions: Insights from American homebrewers', Journal of Small Business Management 55(1), 170-188. https://doi.org/10.1111/ jsbm.12242

Bird, B., 1988, 'Implementing entrepreneurial ideas: The case for intention', Academy of Management Review 13(3), 442-453. https://doi.org/10.5465/amr.1988. 4306970

Bird, B., 1995, 'Towards a theory of entrepreneurial competency', Advances in Entrepreneurship, Firm Emergence and Growth 2(1), 51-72.

Boyd, N.G. \& Vozikis, G.S., 1994, 'The influence of self-efficacy on the development of entrepreneurial intentions and actions', Entrepreneurship Theory and Practice 18(4), 63-63. https://doi.org/10.1177/104225879401800404

Bronowitz, J.B. \& Rader, M.H., 2008, 'Evaluation in entrepreneurship education: A pilot study at the WP Carey School of Business', Delta Pi Epsilon 20, pp. 21-24.

Brophy, M. \& Kiely, T., 2002, 'Competencies: A new sector', Journal of European Industrial Training 26(2/3/4), 165-176.

Carter, N.M., Gartner, W.B. \& Reynolds, P.D., 1996, 'Exploring start-up event sequences', Journal of Business Venturing 11(3), 151-166. https://doi. org/10.1016/0883-9026(95)00129-8

Cha, M.S. \& Bae, Z.T., 2010, 'The entrepreneurial journey: From entrepreneurial intent to opportunity realization', The Journal of High Technology Management Research 21(1), 31-42. https://doi.org/10.1016/j.hitech.2010.02.005

Davidsson, P. \& Honig, B., 2003, 'The role of social and human capital among nascent entrepreneurs', Journal of Business Venturing 18(3), 301-331. https://doi. org/10.1016/S0883-9026(02)00097-6

Dyer, J.H., Gregersen, H.B. \& Christensen, C., 2008, 'Entrepreneur behaviors, opportunity recognition, and the origins of innovative ventures', Strategic Entrepreneurship Journal 2(4), 317-338. https://doi.org/10.1002/sej.59

Farrington, S.M., Venter, D.J., Schrage, C.R. \& Van der Meer, P.O., 2012, 'Entrepreneurial attributes of undergraduate business students: A three country comparison revisited', South African Journal of Economic and Management Sciences 15(4) revisited', South African Journal of Economic and

Fayolle, A., Gailly, B. \& Lassas-Clerc, N., 2006, 'Assessing the impact of entrepreneurship education programmes: a new methodology', Journal of European Industrial Training 30(9), 701-720. https://doi.org/10.1108/03090590610715022

Fayolle, A., Kyrö, P. \& Liñán, F., 2015, Developing, shaping and growing entrepreneurship, Edward Elgar Publishing, Cheltenham.

Feldman, D.C. \& Bolino, M.C., 2000, 'Career patterns of the self-employed: Career motivations and career outcomes', Journal of Small Business Management 38(3), 53-67.

Fini, R., Grimaldi, R., Marzocchi, G.L. \& Sobrero, M., 2009, 'The foundation of entrepreneurial intention', Summer Conference, Selangor, Malaysia, 17th August, pp. 17-19.

Gibson, D., Harris, M.L., Mick, T.D. \& Burkhalter, T.M., 2011, 'Comparing the entrepreneurial attitudes of university and community college students', Journal of Higher Education Theory and Practice 11(2), 11-19.

Giordano Martínez, K.R., Herrero Crespo, Á. \& Fernández-Laviada, A., 2017, 'Influence of perceived risk on entrepreneurial desirability and feasibility: Multidimensional approach for nascent entrepreneurs', Journal of Risk Research 20(2), 218-236. https://doi.org/10.1080/13669877.2015.1042506

Gorman, G., Hanlon, D. \& King, W., 1997, 'Some research perspectives on entrepreneurship education, enterprise education and education for small business management: A ten-year literature review', International Small Business Journal 15(3), 56-77. https://doi.org/10.1177/0266242697153004

Groves, K.S., Vance, C.M., Choi, D.Y. \& Mendez, J.L., 2008, 'An examination of the nonlinear thinking style profile stereotype of successful entrepreneurs', Journal of Enterprising Culture 16(02), 133-159. https://doi.org/10.1142/S0218495808000077

Hair, J.F., Black, W.C., Babin, B.J. \& Anderson, R.E., 2010, Multivariate data analysis, Pearson Prentice Hall, New Jersey, NJ.

Hazlina Ahmad, N., Ramayah, T., Wilson, C. \& Kummerow, L., 2010, 'Is entrepreneurial competency and business success relationship contingent upon business environment? A study of Malaysian SMEs', International Journal of Entrepreneuria Behavior\&Research16(3),182-203.https://doi.org/10.1108/13552551011042780

Herrington, M. \& Kew, P., 2016, Global entrepreneurship monitor (gem): 2015/16 South African report, UCT Graduate School of Business, Cape Town. 
Hmielski, K. \& Corbett, A.C., 2006, 'Proclivity for improvisation as a predictor of entrepreneurial intentions', Journal of Small Business Management 44(1), 45-63. https://doi.org/10.1111/j.1540-627X.2006.00153.X

Hu, L. \& Bentler, P.M., 1999, 'Cutoff criteria for fit indexes in covariance structure analysis: Conventional criteria versus new alternatives', Structural Equation Modeling 6(1), 1-55. https://doi.org/10.1080/10705519909540118

Ibrahim, A. \& Abdullahi, U.M., 2014, 'Analysis of mind-set (intention and constraints) of Nigerian students towards entrepreneurship in the country', Journal of Education and Practice 5(24), 86-93.

Ibrahim, N.A. \& Lucky, E.O.I., 2014, 'Relationship between entrepreneurial orientation, entrepreneurial skills, environmental factor and entrepreneurial intention among Nigerian students in UUM', Entrepreneurship and Innovation Management Journal 2(4), 203-213.

Kaur, H. \& Bains, A., 2013, 'Understanding the concept of entrepreneur competency', Journal of Business Management \& Social Sciences Research 2(11), 31-33.

Kefela, G.T., 2011, 'Entrepreneurship has emerged as the economic engine and socia development throughout the world', Journal of Asian Business Strategy 1(4), 45-53.

Kelley, D., Singer, S. \& Herrington, M., 2017, Global entrepreneurship monitor: Global report 2016/17, viewed 28 August 2017, from http://www.gemconsortium.org/ report/49812.

Kiggundu, M.N., 2002, 'Entrepreneurs and entrepreneurship in Africa: What is known and what needs to be done', Journal of Developmental Entrepreneurship 7(3), 239-258.

Kolvereid, L., 1996, 'Organizational employment versus self-employment: Reasons for career choice intentions', Entrepreneurship Theory and Practice 20(3), 23-32. https://doi.org/10.1177/104225879602000302

Krueger, N.F., 1993, 'The impact of prior entrepreneurial exposure on perceptions of new venture feasibility and desirability', Entrepreneurship Theory and Practice 18(1), 5-21. https://doi.org/10.1177/104225879301800101

Krueger, N.F., Reilly, M.D. \& Carsrud, A.L., 2000, 'Competing models of entrepreneurial intentions', Journal of Business Venturing 15(5), 411-432. https://doi. org/10.1016/S0883-9026(98)00033-0

Krueger, N. \& Welpe, I., 2014, 'Neuroentrepreneurship: What can entrepreneurship learn from neuroscience', in M.H. Morris (ed.), Annals of entrepreneurship education and pedagogy, pp. 60-90, Edward Elgar, New Jersey, NJ.

Krueger, N.F., 2017, 'Entrepreneurial intentions are dead: Long live entrepreneurial intentions', in M. Brännback \& A.L. Carsrud (eds.), Revisiting the entrepreneurial mind, pp. 13-34, Springer, Cham, Switzerland.

Kundu, S.K. \& Katz, J.A., 2003, 'Born-international SMEs: Bi-level impacts of resources and intentions', Small Business Economics 20(1), 25-47. https://doi. org/10.1023/A:1020292320170

Liska, A., 1984, 'A critical examination of the causal structure of the Fishbein/Ajzen attitude behavior model', Social Psychology Quarterly 47(1), 61-74. https://doi. org $/ 10.2307 / 3033889$

Lüthje, C. \& Franke, N., 2003, 'The "making" of an entrepreneur: Testing a model of entrepreneurial intent among engineering students at MIT', R\&D Management 33(2), 135-147. https://doi.org/10.1111/1467-9310.00288

Man, T.W., Lau, T. \& Chan, K., 2002, 'The competitiveness of small and medium enterprises: A conceptualization with focus on entrepreneurial competencies' Journal of Business Venturing 17(2), 123-142. https://doi.org/10.1016/S0883 9026(00)00058-6

Mangundjaya, W.H., 2009, 'The relationship of resilience and entrepreneuria intentions', International Entrepreneurship Congress 2009, 'SMEs and intentions', International Entrepreneurship Congress 2009,
Entrepreneurship', Izmir, Turkey, 14-16th October, pp. 199-204.

Marcati, A., Guido, G. \& Peluso, A.M., 2008, 'The role of SME entrepreneurs' innovativeness and personality in the adoption of innovations', Research Policy 37(9), 1579-1590. https://doi.org/10.1016/j.respol.2008.06.004

McMullen, J.S. \& Shepherd, D.A., 2006, 'Entrepreneurial action and the role of uncertainty in the theory of the entrepreneur', Academy of Management Review 31(1), 132-152. https://doi.org/10.5465/amr.2006.19379628

Mitchelmore, S. \& Rowley, J., 2010, 'Entrepreneurial competencies: A literature review and development agenda', International Journal of Entrepreneuria Behavior\& Research 16(2), 92-111.https://doi.org/10.1108/13552551011026995

Morris, M.H., Webb, J.W., Fu, J. \& Singhal, S., 2013, 'A competency-based perspective on entrepreneurship education: Conceptual and empirical insights', Journal of Small Business Management 51(3), 352-369. https://doi.org/10.1111/jsbm.12023

Morrison, A., Breen, J. \& Ali, S., 2003, 'Small business growth: Intention, ability, and opportunity', Journal of Small Business Management 41(4), 417-425. https://doi. org/10.1111/1540-627X.00092

Nabi, G., Holden, R. \& Walmsley, A., 2010, 'Entrepreneurial intentions among students: Towards a re-focused research agenda', Journal of Small Business and Enterprise Development 17(4), 537-551. https://doi.org/10.1108/14626001011088714

Nieman, G.H. \& Nieuwenhuizen, C., 2014, Entrepreneurship: A South African perspective, 3rd edn., Van Schaik, Pretoria.

Nunnally, J., 1978, Psychometric theory, 2nd edn., McGraw-Hill, New York.
Obschonka, M., Silbereisen, R.K. \& Schmitt-Rodermund, E., 2010, 'Entrepreneurial intention as developmental outcome', Journal of Vocational Behavior 77(1), 63-72. https://doi.org/10.1016/j.jvb.2010.02.008

Pallant, J., 2001, SPSS survival manual: A step by step guide to data analysis using SPSS for Windows (versions 10 and 11), Open University Press, Maidenhead, Buckingham.

Parente, R. \& Feola, R., 2013, 'Entrepreneurial intent and entrepreneurial commitment of young researchers', International Journal of Technology Management \& Sustainable Development 12(2), 155-166. https://doi.org/10.1386/tmsd.12.2.155_1

Pendame, R., 2014, 'Entrepreneurial intent and perseverance among South African students', PhD dissertation, University of the Witwatersrand.

Pfeifer, S., Šarlija, N. \& Zekić Sušac, M., 2016, 'Shaping the entrepreneurial mindset: Entrepreneurial intentions of business students in Croatia', Journal of Small Business Management 54(1), 102-117. https://doi.org/10.1111/jsbm.12133

Rezazadeh, A. \& Nobari, N., 2018, 'Antecedents and consequences of cooperative entrepreneurship: A conceptual model and empirical investigation', International Entrepreneurship and Management Journal 14(2), 479-507. https://doi.org/ Entrepreneurship and Man

Reitan, B., 1996, 'Entrepreneurial intentions: A combined models approach', 9th Nordic small business research conference, Lillehammer, Norway, 29th May, pp. 29-31.

Reynolds, P.D., 2007, 'New firm creation in the United States a PSED I overview' Foundations and Trends in Entrepreneurship 3(1), 1-150. https://doi.org/10.1561/ 0300000010

Schein, E.H. \& Schein, E., 1978, Career dynamics: Matching individual and organizational needs, Addison-Wesley, Reading, MA.

Schwarz, E.J., Wdowiak, M.A., Almer-Jarz, D.A. \& Breitenecker, R.J., 2009, 'The effects of attitudes and perceived environment conditions on students' entrepreneurial intent: An Austrian perspective', Education+ Training 51(4), 272-291. https://doi. org/10.1108/00400910910964566

Singh, B., Verma, P. \& Rao, M., 2016, 'Influence of individual and socio-cultural factors on entrepreneurial intention', South Asian Journal of Management 23(1), 33.

Shane, S. \& Venkataraman, S., 2000, 'The promise of entrepreneurship as a field of research', Academy of Management Review 25(1), 217-226. https://doi. org/10.5465/amr.2000.2791611

Shaver, K.G. \& Scott, L.R., 1991, 'Person, process, choice: The psychology of new venture creation', Entrepreneurship Theory and Practice 16(2), 23-45. https://doi. org/10.1177/104225879201600204

Short, J.C., Ketchen, Jr. D.J., Shook, C.L. \& Ireland, R.D., 2010, 'The concept of "opportunity" in entrepreneurship research: Past accomplishments and future challenges', Journal of Management 36(1), 40-65. https://doi.org/10.1177/ 0149206309342746

Sookhtanlo, M., Rezvanfar, A., Hashemi, S.M. \& Karaj, I., 2009, 'Psychological capabilities affecting agricultural students' entrepreneurship level: A comparative study', Research Journal of Agriculture and Biological Sciences 5(2), 175-184.

Sternberg, R.J., 2004, 'Successful intelligence as a basis for entrepreneurship', Journa of Business Venturing 19(2), 189-201. https://doi.org/10.1016/S0883-9026(03) 00006-5

Taylor, D.W. \& Thorpe, R., 2004, 'Entrepreneurial learning: A process of co-participation', Journal of Small Business and Enterprise Development 11(2), 203-211. https://doi.org/10.1108/14626000410537146

Thompson, E.R., 2009, 'Individual entrepreneurial intent: Construct clarification and development of an internationally reliable metric', Entrepreneurship Theory and Practice 33(3), 669-694. https://doi.org/10.1111/j.1540-6520.2009.00321.x

Urban, B. \& Richard, P., 2015, 'Perseverance among university students as an indicator of entrepreneurial intent', South African Journal of Higher Education 29(5), 263-278.

Volery, T., Müller, S., Oser, F., Naepflin, C. \& Rey, N., 2013, 'The impact of entrepreneurship education on human capital at upper-secondary level', Journal of Small Business Management 51(3), 429-446. https://doi.org/10.1111/jsbm.12020

Wakkee, I., Elfring, T. \& Monaghan, S., 2010, 'Creating entrepreneurial employees in traditional service sectors', International Entrepreneurship and Management Journal 6(1), 1-21. https://doi.org/10.1007/s11365-008-0078-z

Weinert, F.E., 2001, 'Concept of competence: A conceptual clarification', in D.S. Rychen $\&$ L.H. Salganik (eds.), Defining and selecting key competencies, pp. 45-65, Hogrefe \& Huber, Ashland, $\mathrm{OH}$.

Zafar, M.J., Yasin, G. \& ljaz, M., 2012, 'Social networking a source for developing entrepreneurial intentions among entrepreneurs: A case of Multan', Asian Economic and Financial Review 2(8), 1072

Zampetakis, L.A. \& Moustakis, V., 2006, 'Linking creativity with entrepreneurial intentions: A structural approach', The International Entrepreneurship and Management Journal 2(3), 413-428. https://doi.org/10.1007/s11365-006-0006-z

Zhao, H. \& Seibert, S.E., 2006, 'The big five personality dimensions and entrepreneurial status: A meta-analytical review', The Journal of Applied Psychology 91(2), 259-271. https://doi.org/10.1037/0021-9010.91.2.259

Zhao, H., Seibert, S.E. \& Lumpkin, G.T., 2010, 'The relationship of personality to entrepreneurial intentions and performance: A meta-analytic review', Journal of Management 36(2), 381-404. https://doi.org/10.1177/0149206309335187 